\title{
Complex Civil Litigation and the Seventh Amendment Right to a Jury Trial
}

The seventh amendment requires that in "Suits at common law . . . the right of trial by jury shall be preserved." Beginning with Justice Story's 1812 opinion on circuit in United States $v$. Wonson, ${ }^{2}$ the accepted interpretation of the amendment has been that it guarantees the right to trial by jury in all civil proceedings that, had they been brought in England in 1791, would have been tried at common law. "This "flexible" historical test lent itself to straightforward application when it was first articulated in the nineteenth century, ${ }^{4}$ because litigation of that period bore a close resemblance to that of the late eighteenth century. ${ }^{5}$

Application of the test in recent years, however, has not always been so easy. ${ }^{\circ}$ The last fifty years have seen a tremendous liberalization of civil procedure ${ }^{7}$ and an unprecedented proliferation of new causes of action, ${ }^{8}$ which together make it possible for civil litigation to reach a level of "complexity exceeding anything imaginable in the common law courts of 1791. Modern securities and antitrust cases, for example, can involve an enormous number of parties and claims, highly technical factual inquiries, tremen-

1 U.S. Const. amend. VII. The full text of the amendment reads as follows:

In Suits at common law, where the value in controversy shall exceed twenty dollars, the right of trial by jury shall be preserved, and no fact tried by a jury, shall be otherwise re-examined in any Court of the United States, than according to the rules of the common law.

28 F. Cas. 745 (C.C.D. Mass. 1812) (No. 16,750).

- See, e.g., Devlin, Equity, Due Process and the Seventh Amendment: A Commentary on the Zenith Case, 81 Mich. L. Rrv. 1571, 1572 (1983).

- See infra notes 170-79 and accompanying text.

- For example, Wonson is itself an instance of the ancient common law action of debt upon a statutory penalty. See infra notes 99-100 and accompanying text. In Wonson, the "action was debt for a penalty incurred under the $3 \mathrm{~d}$ section of the embargo supplementary act, Jan. 9, 1808, c.8 [2 Stat. 453]." 28 F. Cas. at 745.

- See F. Jamrs \& G. Hazard, Civil Procedure § 8.2 (2d ed. 1977); 5 J. Moore, J. Lucas \& J. Wicker, Moore's Fedrral Practice T 38.08[5] (2d ed. 1982); 9 C. Wright \& A. Miller, Frderal Practice and Procedurs § 2302 (1971).

7 The Federal Rules of Civil Procedure were first adopted in 1938. See Fed. R. Civ. P. 86 (1938), in 308 U.S. 645, 766 (1939).

- See Annual Rbport of the Director of the Adminstrative Office of the U.S. Courts 3 (1980) (Table 3: Civil Cases Filed, Terminated, and Pending on June 30, 19401980); id. at 61 (Table 19: Civil Cases Commenced in the U.S. District Courts, by Nature of Suit, During the Twelve Month Periods Ended June 30, 1975-1980). 
dous volumes of documentary evidence, and trials lasting several years. ${ }^{\circ}$ Even when confronted with exceedingly complex litigation, some courts have refused to foreclose jury trial, holding that complexity is not a constitutionally appropriate ground for denying a jury. ${ }^{10}$ Yet other federal courts have denied demands for a jury trial in complex cases, generally resting their decisions on one of two grounds: first, that a trial of a such a case to an uncomprehending jury would constitute a denial of due process; ${ }^{11}$ and second, that such cases are inherently beyond the understanding of a jury, so that trying them to a jury would constitute an inade-

- For example, in Zenith Radio Corp. v. Matsushita Elec. Indus. Co. (In re Japanese Elec. Prods. Antitrust Litig.), 478 F. Supp. 889 (E.D. Pa. 1979), vacated, 631 F.2d 1069 (3d Cir. 1980), the district court refused to strike a jury demand despite the fact that "the trial would last a full year" and that nine years of discovery had produced "millions of documents and over 100,000 pages of depositions." 631 F.2d at 1073. The suit alleged a conspiracy among 24 named defendants, almost 100 other co-conspirators, and the Japanese government to maintain artificially low prices for Japanese electronic products. Id. at 1072-73 \& nn. 1-2. Plaintiffs sought recovery under the Sherman Act, 15 U.S.C. $\S \S 1-7$ (1982), the Wilson Tariff Act, 15 U.S.C. $\S \S 8-9$ (1982), the Antidumping Act, 15 U.S.C. $\S 72$ (1982), the Clayton Act, 15 U.S.C. $\S \$ 12-27$ (1982), and the Robinson-Patman Price Discrimination Act, 15 U.S.C. $\S \S 13(a)-(b), 21$ (a) (1982). 631 F.2d at 1072. Some of the defendants counterclaimed against the plaintiffs and 30 other co-conspirators for violations of the Lanham Act, 15 U.S.C. $\$ \S 1051-1127$ (1982), as well as the Sherman and Robinson-Patman Acts. 631 F.2d at 1072-73. In essence, the case required a jury to evaluate the conduct of the entire Japanese electronics industry and its distributors around the world during the late 1960's and most of the 1970's. The Third Circuit vacated the district court's ruling and held that the case was too complex for a jury trial. Id. at 1069.

The district court in In re U.S. Fin. Sec. Litig., 75 F.R.D. 702 (S.D. Cal. 1977), rev'd, 609 F.2d 411 (9th Cir. 1979), cert. denied, 446 U.S. 929 (1980), struck the jury demands on the grounds that the case was too complex. In that dispute, five classes of plaintiffs were aligned in 18 consolidated lawsuits against over 100 defendants. Three years of discovery had produced 150,000 pages of depositions and over 5 million documents. Id. at 707. The judge estimated that the documents likely to be offered into evidence at trial would be equivalent to the first 90 volumes of the second series of the Federal Reporter. Id. The trial was expected to exceed two years, $i d$. at 713-14, and the judge was unsure whether there was a courtroom large enough to hold all the attorneys, let alone the jurors and alternates, id. at 715. See also Bernstein v. Universal Pictures, Inc., 79 F.R.D. 59 (S.D.N.Y. 1978) (65 named plaintiffs, representing up to 1100 class members, sued 11 defendants for antitrust violations in connection with 1050 separate contracts); ILC Peripherals Leasing Corp. v. IBM, 458 F. Supp. 423 (N.D. Cal 1978) (five-month trial involving complex technical and financial issues, 2300 exhibits, and 19,000 pages of transcript, in which the jury, after 19 days of deliberation, declared itself hopelessly deadlocked), aff'd per curiam, 636 F.2d 1188 (9th Cir. 1980); In re Boise Cascade Sec. Litig., 420 F. Supp. 99 (W.D. Wash. 1976) (an expected four to six months of trial, with 900,000 documents produced in discovery, involving complex accounts relating to over $\$ 1$ billion in assets and liabilities arising out of over five years of financial activities).

${ }^{10}$ See, e.g., In re U.S. Fin. Sec. Litig., 609 F.2d 411 (9th Cir. 1979), cert. denied, 446 U.S. 929 (1980).

1 See, e.g., Zenith Radio Corp. v. Matsushita Elec. Indus. Co. (In re Japanese Elec. Prods. Antitrust Litig.), 631 F.2d 1069 (3d Cir. 1980). 
quate remedy at law. In the latter situation, the jurisprudence of 1791 would have required that the case be brought in equity, where there would have been no jury trial. ${ }^{12}$

The question of the propriety of jury trials in complex civil litigation, and the constitutionality of precluding them, has engendered considerable academic commentary. Lord Devlin has argued that in 1791 the equity courts of England exercised the power to prevent especially complex cases from being tried to juries in the common law courts and that federal courts, in their equity capacity, retain this power under the seventh amendment. ${ }^{13}$ In response to Devlin's assertion, Professor Arnold has sought to demonstrate the absence of such a "complexity" exception. ${ }^{14}$

This comment considers the question of the requirements of

12 See, e.g., Bernstein v. Universal Pictures, Inc., 79 F.R.D. 59 (S.D.N.Y. 1978). An inadequate remedy at law was the most common justification for the exercise of equity jurisdiction. See J. Story, Commentarias on Equity JuRIsprudence 32 (Boston 1836) ("Perhaps the most general, if not the most precise, description of a Court of Equity, in the English and American sense, is, that it has jurisdiction in cases of rights recognised and protected by the municipal jurisprudence, where a plain, adequate, and complete remedy cannot be had in the Courts of Common Law."); Devlin, Jury Trial of Complex Cases: English Practice at the Time of the Seventh Amendment, 80 Colum. L. Rev. 43, 51-53 (1980); Note, The Right to Jury Trial in Complex Civil Litigation, 92 Hakv. L. Rev. 898, 900-01 (1979).

1s See Devlin, supra note 12. In a subsequent article, Lord Devlin has bolstered his argument for the retained equity power of federal courts to foreclose jury trials in complex cases by analogizing to modern due process jurisprudence. Due process, Devlin argues, has come to serve a similar function to that served in 1791 by the notion of "lack of equity." Under either concept, a court is authorized, where strict application of normal procedural rules would work a notable unfairness on one of the parties, to adjust those rules and mold ones specially tailored to the peculiar circumstances of the particular case. Devlin, supra note 3, at 1583-1607. Lord Devlin's first article, in which he concluded that there was a complexity exception to the right to jury trial at common law, represents research commissioned by IBM for use in its amicus curiae briefs in Zenith Radio Corp. v. Matsushita Elec. Indus. Co. (In re Japanese Elec. Prods. Antitrust Litig.), 631 F.2d 1069 (3d Cir. 1980), in In re U.S. Fin. Sec. Litig., 75 F.R.D. 702 (S.D. Cal. 1977), rev'd, 609 F.2d 411 (9th Cir. 1979), cert. denied, 446 U.S. 929 (1980), and in IBM's own party brief in ILC Peripherals Leasing Corp. v. IBM, 458 F. Supp. 423 (N.D. Cal. 1978), aff'd per curiam, 636 F.2d 1188 (9th Cir. 1980). See Japanese Electronics Prods., 631 F.2d at 1083 (discussion of IBM's role in the litigation); U.S. Fin. Sec. Litig., 609 F.2d at 418 n.17 (same); see also Lempert, Civil Juries and Complex Cases: Let's Not Rush to Judgment, 80 Mrch. L. Rev. 68, 74 (1981) ("The leading arguments in the historical debate have been propounded by people who, however disinterested their actual scholarship, were employed by one side in a lawsuit and paid-no doubt handsomely - for reaching the results they did.").

Is See Arnold, A Historical Inquiry into the Right to Trial by Jury in Complex Civil Litigation, 128 U. PA. L. Rev. 829 (1980). Professor Arnold's article is an abridgement of a monograph produced for the plaintiffs in Zenith Radio Corp. v. Matsushita Elec. Indus. Co. (In re Japanese Elec. Prods. Antitrust Litig.), 631 F.2d 1069 (3d Cir. 1980). See Arnold, supra, at 1082 n.12; Lempert, supra note 13, at 74. Professor Arnold examines the same cases as Lord Devlin (compare Devlin, supra note 12) and concludes that they are "much too frail" to support a complex case exception to common law jurisdiction. Arnold, supra, at 840 . 
the seventh amendment in modern, complex litigation from another perspective. It argues that, in order to understand the scope of the seventh amendment in such cases, it is necessary to consider the understanding of the amendment's framers as to the nature of "Suits at common law." To develop an understanding of the perspective of the framers, the comment reviews common law litigation in the principal English courts during the years 1789 to 1791 . Part I presents a brief overview of the mechanics of English common law litigation during this period and demonstrates that the procedural framework limited the role of the jury to deciding a very few and very simple questions of fact. Part II presents a statistical survey of the actual litigation of the period, which demonstrates the simplicity of the cases submitted to common law juries in contrast to those tried by the court in equity.

Part III considers the implications of this evidence both for Lord Devlin's search for a "complex cases" exception and for the law as it now stands. It concludes that the common law recognized no complex case exception because the procedural limits within which the jury functioned insured that no complex cases would ever reach the jury. Part III also concludes that the current exclusive focus on the rights adjudicated or the remedies available in suits at common law in 1791 is misguided. Although the comment acknowledges that a comparison of the right asserted and the remedy requested by a modern plaintiff with the rights and remedies available at common law in 1791 is always significant, and perhaps, in the usual case, dispositive, it argues that, insofar as modern procedural reforms allow plaintiffs to bring suits that bear virtually no resemblance, outside of the right of remedy, to suits at common law in 1791, it is improper to ignore entirely the effect of those procedural reforms. The comment argues that a proper analysis of the scope of the constitutional right to a civil jury trial must include not only an examination of the nature of the rights asserted and the remedies requested by the plaintiff, but also an inquiry into the procedural complexity of a case. The comment concludes that, under this analysis, an extraordinarily complex case may be outside the ambit of the seventh amendment.

\section{A Survey of Various Aspects of English Civil Cases in 1791}

Although the Constitution as adopted in 1789 contained no provision guaranteeing a right to jury trial in civil, as opposed to 
criminal, ${ }^{15}$ cases, the delegates at the constitutional convention had considered and ultimately rejected such a clause. ${ }^{16}$ The absence of such a clause was a frequent source of objection in the state conventions called to ratify the original constitution, ${ }^{17}$ and, in response, the first Congress included the seventh amendment in the Bill of Rights. ${ }^{18}$ Although, as Madison noted, the right to a civil jury trial was "a subject [the people had] much at heart,"19 and may well have engendered considerable discussion in Congress when the seventh amendment was proposed, no record of the congressional debates has been preserved. ${ }^{20}$ Even the debate on the similar provision considered at the constitutional convention is notably unilluminating as to the scope of the jury right intended by that provision's proponents. ${ }^{21}$ In light of this dearth of explanation

15 A guarantee of jury trial in criminal cases was included in the original Constitution. U.S. CoNsT. art. III, $\S 2$, para. 3.

${ }^{16}$ Although the evidence is not conclusive, it appears that the draft of the Constitution passed from the floor of the Convention to the Committee of Detail and then to the Committee on Style and Arrangement before the framers considered a jury guarantee for civil actions. See Henderson, The Background of the Seventh Amendment, 80 Harv. L. REv. 289, 292-95 (1966); Wolfram, The Constitutional History of the Seventh Amendment, 57 MinN. L. Rav. 639, 656-66 (1973). Delegate Williamson suggested that such a provision be added, and Delegate Gerry supported the proposal on the grounds that it would provide protection from corrupt judges. Delegate Gorham objected: "It is not possible to discriminate equity cases from those in which juries are proper [and the] Representatives of the people may safely be trusted in this matter." 2 Records of the Fedrral Convention or 1787, at 587 (M. Farrand ed. 1937). The discussion turned to a proposal for a general bill of rights, which was overwhelmingly defeated. Several days later, Delegates Pinckney and Gerry formally moved to have the following language added to the Constitution: "And a trial by jury shall be preserved as usual in civil cases." Id. at 628. Delegates Gorham and King, however, objected, stating that different states constituted their juries differently and used them in different types of actions; the proposed amendment was subsequently rejected. Id. at 629 .

17 See Henderson, supra note 16, at 295-99; Wolfram, supra note 16, at 667-725.

18 See Henderson, supra note 16, at 291-92; Wolfram, supra note 16, at 725-30.

191 AnNals or Congress 444 (J. Gales ed. 1789). Madison made this statement in connection with a proposal that article III of the Constitution be amended by adding at the end: "But no appeal to such court shall be allowed where the value in controversy shall not amount to-dollars: nor shall any fact triable by jury, according to the course of common law, be otherwise re-examinable than may consist with the principles of common law." Id. at 452. Madison also proposed that the third clause of article III, $\S 2$, be replaced, in part, by the words, "In suits at common law, between man and man, the trial by jury, as one of the best securities to the rights of the people, ought to remain inviolate." Id. at 453. Madison's phrase, "between man and man," suggests that he conceived of the typical action for which jury trial was appropriate as a simple contest between two individuals. Madison's source for the phrase was probably the declaration of rights adopted by the Virginia convention that ratified the Constitution. See 3 The Debates in the Sevrral State Conventions on the Adoption of the FEderal Constitution 658 (J. Elliot 2d ed. n.p. 1854) (1st ed. Washington 1836).

20 Wolfram, supra note 16 , at 729-30.

21 "Although the surviving records of the proceedings of the Philadelphia Convention 
by the amendment's framers, one is forced to rely on an examination of the context in which the amendment was drafted in order to discern the likely meaning that the framers attached to the amendment. Accordingly, this Part presents a brief, general outline of the procedural and substantive character of cases in the English common law courts at the time of the amendment's adoption, while the next Part presents a statistical survey of the cases reported in the major courts of England in the three years preceding the adoption of the seventh amendment.

Three major common law courts existed in England in 1791: Exchequer, Common Pleas, and King's Bench. ${ }^{22}$ The Chancery was the principal court of equity. ${ }^{23}$ The development of the various English courts was not the product of a systematic plan, but rather the result of a process of institutional evolution that spanned several centuries. Each court typically grew out of the administrative specialization of a group of royal officers that, as it developed increasing expertise and began to act more independently of the monarch, came to function as a quasi-independent institution. ${ }^{24}$ Because each court developed at a different time, each adopted significantly different procedures. ${ }^{25}$

One crucial feature shared by all common law courts, however, was the writ system. A writ was originally a royal order to an individual "to redress the wrong he was said to have done" or to appear before the court and explain to the royal justices why he had not redressed it. ${ }^{26}$ Later, the defendant was no longer given the opportunity simply to redress the wrong, and writs came to be the

are sketchy, it is almost certain that altogether not more than an hour or so was spent on the subject of jury trials." Id. at 660 n.50.

22 J. Baker, AN Introduction to Legal History 46 (2d ed. 1979). The following discussion is not intended to be an exhaustive survey of the structure of the English judicial system, merely an effort to frame the statistical evidence presented in Part II. For a more comprehensive study of the development of the English judicial system, see 1 W. HoLnsWORTH, History OR ENGLISH LAw 194-264 (1931). For a discussion of the reform of the court system beginning in the early nineteenth century, see id. at 633-50.

${ }^{23} \mathrm{~J}$. BAKER, supra note 22, at 86-89. For descriptions of the lesser courts of equity, see J. BAKRR, supra note 22, at 103-06 (Court of Requests and regional equity courts); W. Bryson, The EquTTY SIDE OF THE EXCHEQUER passim (1975).

24 See T. Plucknett, A Concise History or the Common Law 146 (5th ed. 1956); see also id. at 139-56.

${ }^{25} 1$ W. Tidd, The Practice of the Courts of King's Bench and Common Pleas, in Personal Actrons xxxix (6th ed. London 1817) (1st ed. Dublin 1791) (discussion of differences in "the nature of the process used for bringing in the defendant, . . . the manner in which [process] is returnable, the times prescribed or allowed for particular purposes, and the modes of transacting business by the court or its officers").

${ }^{28}$ R. van Caenegem, Royal Writs in England from the Conquest to Glanville 244 (1959) (77 Selden Soc'y). 


\section{method for initiating suit in the royal courts. ${ }^{27}$}

The writs were specialized, so that a separate writ existed for each civil wrong. Each writ corresponded to a separate "form of action," which was defined according to the specific nature of the wrong alleged. ${ }^{28}$ Because the forms of action were defined both narrowly and precisely, this system severely limited the subject matter of any single lawsuit. ${ }^{2 \theta}$ A plaintiff could not merely allege injury by another; he had to determine the precise nature of the legal wrong before procuring his writ. ${ }^{30}$ Presenting one's claims under the wrong writ or alleging facts inappropriate to the nature of the writ chosen meant losing the suit. ${ }^{31}$ In addition, one writ

${ }^{27}$ D. Stenton, English Justice Between the Norman Conquest and the Great CharTRR 1066-1215, at 32-33 (1964); R. VAN CAENEGEM, supra note 26, at 244-48; see F. Maitland, The Forms of action at Common Law 21-26 (1948).

${ }^{28}$ See T. PluckNeTt, supra note 24, at 353-57. By the 1790 's a plaintiff could sometimes forego obtaining an original writ and could instead proceed directly to serving process upon a defendant by capias in Common Pleas or by bill of Middlesex or latitat in King's Bench. 4 Select Cases in the Court of King's Bench Under Edward II, at loxxv (G. Sayles ed. 1957) (74 Selden Soc'y) ("Apart from the substitution of an originating bill for an originating writ and the quickening of process, there is no discernible difference from process by writ: procedure, pleadings, trial, judgment, punishment, recovery of damages, all these remain precisely the same."); see also $3 \mathrm{~W}$. Blackstone, Commentaries *279-92 (chapter "Of Process"); 9 W. HoldsworTh, supra note 22, at 250, 341 (process not by original writ); $1 \mathrm{~W}$. Tiod, supra note 25, at 95-96 (process by capias or bill of Middlesex).

29 See W. BlackstoNE, supra note 28 , at *153-66. For example, certain contractual claims, such as payment of a bond, would be brought under a writ of debt; others, such as enforcement of an insurance claim, under a writ of covenant; still others, such as suit on a mere promise, under a writ of assumpsit. See id.; F. MartuAND, Seven Lectures on the Forms of Action, in Equity ANd The Forms of Action at Common Law 355-58 (1909). Certain tort claims could only be tried in trespass, whereas others required a writ of trespass on the case. See W. Blackstone, supra note 28 , at *120-27.

${ }^{30}$ For an example of the classification of injuries into their proper writs, see 6 G. JACOB, The Law Dictionary 288 (New York 1811) (1st ed. London 1729):

It is a settled distinction, that where an act is done which is in itself an immediate injury to another's person or property, there the remedy is usually by an action of Trespass vi et armis: But where there is no act done, but there is only a culpable omission, or where the act is not immediately injurious, but only by consequence and collaterally, there no action of Trespass vi et armis will lie, but an action on the special case for the damages consequent on such omission or act.

Similarly, if a plaintiff sought return of his property from another, he had to choose the proper writ. As Holdsworth explained: "Trespass de bonis asportatis lay for a wrongful taking of the plaintiff's chattels by the defendant from the plaintiff's possession; detinue lay for the wrongful detention of the plaintiff's chattels by the defendant; and trover lay for the wrongful conversion or disposition of the plaintiff's chattels by the defendant." 7 W. HoLDsWORTH, supra note 22 , at 403 .

${ }^{31}$ A litigant "may make a bad choice [of writs], fail in his action, and take such comfort as he can from the hints of the judges that another form of action might have been more successful." F. MartLAND, supra note 27 , at 4 . The harshness of this rule was mitigated by the availability of procedure by capias or bill of Middlesex. See W. BLACKSTONE, supra note 28 , at $* 293-94$. 
could not be amended into a different writ once an action had begun. ${ }^{32}$ Two writs could not ordinarily be presented in the same suit, so that a plaintiff could not attempt to strengthen his case by joining, for example, trespass with case, or trover with detinue. ${ }^{33}$ The general effect of the writ system was to limit the questions in any particular case to a few related issues of fact or law raised by a narrowly defined form of action. ${ }^{34}$ This limitation made it unlikely that a case presented to a jury would involve more than a single transaction among a small number of parties.

Strict rules of pleading further narrowed the scope of the case presented for jury consideration. According to Blackstone:

Every plea must be simple, intire [sic], connected, and confined to one single point: it must never be entangled with a variety of distinct independent answers to the same matter; which must require a many different replies, and introduce a multitude of issues upon one and the same dispute. For this would embarrass the jury, and sometimes the court itself, and at all events would greatly enhance the expense of the parties. ${ }^{35}$

Another writer of the period described the process in these terms: "The defendant answers this declaration; and the charge and defence, by due course of pleading, are brought down to one or more plain simple facts. These facts, arising out of the pleadings, and thence called issues, come next to be tried by a jury."36 This process, called "pleading down to issue," was the most prominent feature of the common law pleading system and was designed to prevent complex problems from overtaxing a jury. ${ }^{37}$

The law of evidence, well developed by $1791,,^{38}$ also restricted the complexity of cases that could be put before a jury. To prove a

32 Although the writ could not be amended, under certain circumstances, a declaration, plea, or replication could be amended. See 2 W. TIDD, supra note 25, at 743-47, 755 .

ss See 6 G. JACOB, supra note 30 , at 458 ("In all Writs care is to be taken, that they be laid and formed according to the cause or ground of them, and so pursued in the process thereof .....").

${ }^{34}$ See infra notes $35-37$ and accompanying text.

${ }^{3 s} 3$ W. Blackstone, supra note 28 , at *311. See also the remark of Lord Kenyon, Chief Justice of the King's Bench: "the use of pleading is to reduce the matters in litigation to a single point . . . ." Douglas v. Patrick, 3 T.R. 683, 684, 100 Eng. Rep. 802, 803 (K.B. 1790) (emphasis added).

${ }^{s B} 1$ W. ThDD, supra note 25 , at $\times x \times i i i$.

37 W. Blackstone, supra note 28 , at *311.

ss See 1 J. Wigmore, A Treatise on the Anglo-American System of Evidence, § 8, at 238 (3d ed. 1940) (By 1790, the "full spring-tide of the system [of evidence] had now arrived."). 
deed, for example, a subscribing witness had to be produced in court, because the law of evidence allowed proof of a person's handwriting only by the testimony of one who had actually seen the signing of the instrument. ${ }^{39}$ Testimonial evidence was severely limited by competence requirements, strict regulation of the form of examination, and strict rules for hearsay. ${ }^{40}$ Because no individual with an interest in the outcome of a suit was allowed to testify, the plaintiff and the defendant were never allowed to take the stand. ${ }^{41}$

No better indicator exists of the dramatic increase wrought by modern rules of procedure and evidence in the complexity of modern civil trials than the increase in their length. In 1791, most trials were exceedingly brief; a trial lasting more than a day was considered extraordinary. ${ }^{42}$ Usually, the jury's deliberation was equally speedy:

The jury, after the proofs are summed up, unless the case be very clear, withdraw from the bar to consider of their verdict: and, in order to avoid intemperance and causeless delay, are to be kept without meat, drink, fire, or candle, unless by permission of the judge, till they are all unanimously agreed. ${ }^{4 s}$

Today a civil trial may last weeks or even months, ${ }^{44}$ and in rare cases trials have gone on for over a year.46

39 $2 \mathrm{~W}$. HoLDSWORTh, supra note 22, at 506.

to See 2 J. Wrgmore, supra note 38, at § 525; 5 id. § 1364.

11 See Bodansky, The Abolition of the Party-Witness Disqualification: An Historical Survey, $70 \mathrm{Ky}$. L.J. 91 (1981); Devlin, supra note 12, at 58. Disqualification of the testimony of interested witnesses persisted in the English common law courts until 1843, and the disqualification of the testimony of parties remained the rule until 1851. Bodansky, supra, at 93.

42 Devlin, supra note 12, at 58.

4s 3 W. Blackstone, supra note 28 , at *375.

11 See, e.g., IlC Peripherals Leasing Corp. v. IBM, 458 F. Supp. 423, 448 (N.D. Cal. 1978) (10-months estimated trial), aff'd per curiam, 636 F.2d 1188 (9th Cir. 1980); Bernstein v. Universal Pictures, Inc., 79 F.R.D. 59, 63 (S.D.N.Y. 1978) (4 months minimum estimate but probably longer because of interruptions required for criminal matters by Speedy Trial Act); Radial Lip Mach., Inc. v. International Carbide Corp., 76 F.R.D. 224, 228 (N.D. Il. 1977) (estimate of "only three weeks"); In re Boise Cascade Sec. Litig., 420 F. Supp. 99, 104 (W.D. Wash. 1976) (4-6 months estimated trial).

4s See, e.g., Zenith Radio Corp. v. Matsushita Elec. Indus. Co. (In re Japanese Elec. Prods. Antitrust Litig.), 478 F. Supp. 889, 897 (E.D. Pa. 1979) (1-year estimated trial), vacated, 631 F.2d 1069 (3d Cir. 1980); In re U.S. Fin. Sec. Litig, 75 F.R.D. 702, 713 (S.D. Cal. 1977) (2-year estimated trial), rev'd, 609 F.2d 411 (9th Cir. 1979), cert. denied, 446 U.S. 929 (1980). 
III. Survey of Litigation in the English Common Law Courts FROM 1789 TO 1791

The observations in the preceding section concerning the nature of common law litigation would lead one to expect that the scope of common law suits, and consequently the role of the jury, was narrowly restricted. In order to test that prediction, this Part provides a statistical analysis of common law jury practice by analyzing all of the reported cases in the major English common law trial courts during the years 1789 to 1791 , the period from the ratification of the Constitution to the ratification of the seventh amendment. ${ }^{46}$ The purpose of the analysis is to examine the actual complexity of lawsuits during this period as an aid in ascertaining the framers' conception of "Suits at common law." The cases are analyzed in terms of those features that together constitute the overall complexity of a suit: the number of parties involved; the amount in controversy; and the nature of the claims. The common law courts are considered first. Published reports exist for only two of the three major English common law courts, Common Pleas and King's Bench, for this period; no reports have been published for the common law side of the Exchequer. ${ }^{47}$ The survey also considers nisi prius reports of the trial phase of cases in the common law courts for the years 1790 and 1791 . For comparison, the survey also examines equity litigation during the same period.

The reporters for this period are generally considered to be highly reliable. ${ }^{48}$ They do not, however, contain reports of all the cases brought during the period. Therefore it is probable that an analysis of the original documents in the English Public Record Office would yield some variation from the results obtained by analyzing only the reported cases. Such variations, of course, would not necessarily call for different conclusions. To the contrary, the systematic bias inherent in law reporting of the period toward

\footnotetext{
46 For the King's Bench and Common Pleas reports, discussed infra notes 50-104 and accompanying text, the period extends from Hilary term, $29 \mathrm{Geo}$. 3, 1789, to Michaelmas term, 32 Geo. 3, 1791. For the nisi prius reports, discussed infra notes 105-27 and accompanying text, it extends from after Easter term, $30 \mathrm{Geo} .3,1790$, to after Michaelmas term, 32 Geo. 3, 1791.

67 Cox's Chancery reports, 29-30 Eng. Rep., cover 1783 to 1796 and include some Exchequer equity cases but no common law cases. The common law Exchequer reports nearest in time to the period examined in this comment appear in Anstruther's reports, 145 Eng. Rep., for 1792 to 1797. See W. BrYson, supra note 23, at 199-200. Though primarily a common law court, the Exchequer also had a limited equitable jurisdiction available to "officers of the exchequer, royal accountants, and debtors to the crown." Id. at 17.
}

48 See infra notes 90,108 and accompanying text. 
cases of interest to the bar is likely to have inflated the average and median sums in controversy; disputes of a simpler, more routine nature are less likely to have been included in the published reports.

Finally, it should be noted that the reports are often not opinions of the court, but the reporter's description of the decisions derived primarily from the reporter's or the judge's notes. ${ }^{48}$ While the thoroughness with which the information is presented varies with the reporter, and while subtle distinctions may have been lost in a rendition of this kind, the reports generally include the primary information necessary for the survey to be undertaken here.

\section{A. The Court of Common Pleas}

In Magna Carta, the barons demanded that some royal judges adjudicate private suits in "some fixed place," rother than, as was the practice up to that the time, all attending the king wherever he travelled. The judges that, in compliance with this demand, remained at Westminster became known in later times as the Court of Common Pleas; the judges that continued to travel with the king later became the Court of King's Bench, a name that the court kept even after forsaking its peripetetic ways. ${ }^{51}$ In the eighteenth century the Court of Common Pleas consisted of a chief justice and three "puisne," or junior, justices. ${ }^{52}$ Most of the available writs could be presented to Common Pleas, though the court never developed a criminal jurisdiction. ${ }^{63}$ It did at one time maintain a monopoly over the real actions by which seisin of a freehold was tried, ${ }^{54}$ but by the eighteenth century the writ of ejectment availa-

49 See, e.g., 1 W. Brown, Reports of Cases Argued and Detrrmined in the Hrgh Court of Chancery preface (4th ed. London 1819) (1st ed. London 1785); T. Prakg, Cases Determined at Nisi Prius, in the Court of King's Bench v-vi (3d ed. London 1820) (1st ed. Dublin 1795).

so Magna Carta c. 17 (1215); see 2 W. Stubbs, The Constitutional History of EngLAND IN ITS ORIGIN AND DeVElopment § 233 (3d ed. 1880) (discussing the development of the English judicial system).

s1 See 2 W. STUBBS, supra note 50, at $\S 233$.

s2 See 3 W. BLACKSToNe, supra note 28 , at *40; see also $6 \mathrm{G}$. JAcoB, supra note 30 , at 343 (definition of "puisne"); J. BAKRR, supra note 22, at 35; cf. 3 W. BLACKSTONE, supra note 28 , at $* 40$ n.n.

${ }^{58}$ See J. BAKER, supra note 22, at 35; T. PlucKNETT, supra note 24, at 155; see also 1 W. HoldSworth, supra note 22, at 201 (error from justices of the peace lies with King's Bench).

st 1. W. HoLDSWORTH, supra note 22 , at 198 \& n.2. 
ble in King's Bench was the more prevalent means of trying the right to possession of land. ${ }^{\text {s5 }}$

Henry Blackstone, the nephew of the better-known William Blackstone, reported the decisions of the Court of Common Pleas from 1788 to $1796 .{ }^{56}$ Blackstone reported 124 cases during the period of 1789-1791.57 Four decisions of the Exchequer Chamber and one from the House of Lords have been excluded from the statistical sample because they were not trial-level cases, and three actions for a writ of prohibition have also been excluded because they were perogative writs and hence did not involve jury trial, leaving 116 Common Pleas cases to be considered here.

1. Parties. A tabulation of the number of parties in these cases reveals the following pattern: ${ }^{58}$

Table 1

No. of Parties

2

3

4 or more
No. of Cases

$76(65.5 \%)$

$18(15.5 \%)$

$22(19.0 \%)$

The typical case in Common Pleas involved only a single plaintiff suing a single defendant. Most of the multiple-party litigation involved a single plaintiff suing a small group; multiple parties were present on both sides in only seven percent of the cases. The category "four or more" parties is used because many of the cases indicate only that "others" were involved. ${ }^{50}$ One should not assume, however, that large numbers of parties were joined. Of the eight cases in this category in which the precise number appears, five were four-party cases, ${ }^{60}$ one was a five-party case, ${ }^{61}$ and two

${ }^{B S} I d$. at 198 \& n.5, 199; see infra note 87 and accompanying text.

${ }^{86} \mathrm{H}$. Blackstone, Reports of Cases Argued and Determined in the Courts of Common Pleas and Exchequer Chamber (5th ed. London 1837) (1st ed. London 1791).

${ }^{57}$ These cases begin at $1 \mathrm{H}$. Bl. 97, 126 Eng. Rep. 58, and continue to $2 \mathrm{H}$. Bl. 16, 126 Eng. Rep. 404. Statistics are derived from these reported cases unless otherwise noted.

${ }_{38}$ The number of parties usually appears in the caption of a case. E.g., Kirkman v. Price, 1 H. Bl. 309, 126 Eng. Rep. 182 (C.P. 1790) (two-party case); Hays \& Another v. Bryant, 1 H. Bl. 253, 126 Eng. Rep. 147 (C.P. 1789) (three-party case); Sumner v. Brady, Cartwright \& Fenton, 1 H. Bl. 647, 126 Eng. Rep. 369 (C.P. 1791) (four-party case). Fourparty cases cannot always be distinguished from cases with more than four parties. E.g., Gunnis \& Others v. Erhart, $1 \mathrm{H}$. Bl. 289, 126 Eng. Rep. 169 (C.P. 1789). In some cases involving more than four parties, the exact number of parties is revealed in the body of the report; in others, however, the exact number cannot be determined.

${ }^{39}$ See supra note 58.

${ }^{\circ 0}$ Sumner v. Brady, 1 H. Bl. 647, 126 Eng. Rep. 369 (C.P. 1791); Arthington v. Bishop of Chester, 1 H. Bl. 418, 126 Eng. Rep. 243 (C.P. 1790); Collins v. Morgan, 1 H. Bl. 244, 126 Eng. Rep. 142 (C.P. 1789); Kilgour v. Finlyson, 1 H. Bl. 155, 126 Eng. Rep. 92 (C.P. 1789); Rose v. Bowler, 1 H. Bl. 108, 126 Eng. Rep. 65 (C.P. 1789).

${ }^{61}$ Barker v. Bishop of London, 1 H. Bl. 412, 126 Eng. Rep. 240 (C.P. 1790). 
were six-party cases. ${ }^{62}$ Moreover, virtually all of the multiple-party suits involved joint liabilities or rights, which effectively reduced them to the same level of party complexity as if the joint interests were held by an individual: five cases involved partnerships, ${ }^{63}$ six involved co-indorsees or payees of a note or bond, ${ }^{64}$ five involved groups of public officials, ${ }^{65}$ two involved sets of assignees in bankruptcy, ${ }^{66}$ four involved coparcenors of an advowson, ${ }^{67}$ and one involved a set of executors. ${ }^{68}$

2. Amounts in Controversy. Thirty-two percent of the reported cases in Common Pleas indicate the amount in controversy. The average amount in controversy was $£ 118018 \mathrm{~s} .2 / 3 \mathrm{~d}$., but this figure is distorted upward by a single action involving $£ 17,600 .^{69}$ The median amount in controversy was $£ 39618$ s.

3. The Forms of Action and the Nature of the Claims. Most of the reported cases in Common Pleas consisted of relatively simple contract, real-property, and tort claims. ${ }^{70}$ The cases reported by Blackstone in which the writ is revealed are summarized below:"1

62 Thrale v. Bishop of London, 1 H. Bl. 530, 126 Eng. Rep. 304 (C.P. 1790); Thrale v. Bishop of London, 1 H. Bl. 376, 126 Eng. Rep. 221 (C.P. 1790).

ss Clay v. Willan, 1 H. Bl. 298, 126 Eng. Rep. 174 (C.P. 1789); Gerard v. DeRobeck, 1 H. Bl. 280, 126 Eng. Rep. 164 (C.P. 1789); Collins v. Morgan, 1 H. Bl. 244, 126 Eng. Rep. 142 (C.P. 1789); Israel v. Douglas, 1 H. Bl. 239, 126 Eng. Rep. 139 (C.P. 1789); Kilgour v. Finlyson, 1 H. Bl. 155, 126 Eng. Rep. 92 (C.P. 1789).

* Davidson v. Lord Foley, 2 H. Bl. 12, 126 Eng. Rep. 401 (C.P. 1791); Sumner v. Brady, 1 H. Bl. 647, 126 Eng. Rep. 369 (C.P. 1791); Newman v. Faucitt, 1 H. Bl. 631, 126 Eng. Rep. 360 (C.P. 1791); Sumner v. Brady, 1 H. Bl. 630, 126 Eng. Rep. 359 (C.P. 1791); Collis v. Emett, 1 H. Bl. 313, 126 Eng. Rep. 185 (C.P. 1790); Kilgour v. Finlyson, 1 H. Bl. 155, 126 Eng. Rep. 92 (C.P. 1789).

os Newman v. Faucitt, 1 H. Bl. 631, 126 Eng. Rep. 360 (C.P. 1791); The King v. Baker, 1 H. Bl. 543, 126 Eng. Rep. 312 (C.P. 1791); Hays v. Bryant, 1 H. Bl. 253, 126 Eng. Rep. 147 (C.P. 1789); Collins v. Morgan, 1 H. Bl. 244, 126 Eng. Rep. 142 (C.P. 1789); Mayor of London v. Mayor of Lenne Regis, 1 H. Bl. 206, 126 Eng. Rep. 119 (C.P. 1789).

se Sill v. Worswick, 1 H. Bl. 665, 126 Eng. Rep. 379 (C.P. 1791); Gray v. Fowler, 1 H. Bl. 462, 126 Eng. Rep. 268 (C.P. 1790) (advisory verdict for case originating in chancery).

67 Thrale v. Bishop of London, 1 H. Bl. 530, 126 Eng. Rep. 304 (C.P. 1790); Arthington v. Bishop of Chester, 1 H. Bl. 418, 126 Eng. Rep. 243 (C.P. 1790); Barker v. Bishop of London, 1 H. Bl. 412, 126 Eng. Rep. 240 (C.P. 1790); Thrale v. Bishop of London, $1 \mathrm{H}$. Bl. 376, 126 Eng. Rep. 221 (C.P. 1790).

${ }^{68}$ Rose v. Bowle, 1 H. Bl. 108, 126 Eng. Rep. 65 (C.P. 1789).

s) Hobson v. Campbell, 1 H. Bl. 245, 126 Eng. Rep. 142 (C.P. 1789).

70 This simplicity is the result of the narrow scope of the forms of action. See supra notes $26-34$ and accompanying text.

21 The table includes only 74 cases (64\% of the trial-level Common Pleas cases) because in many of the cases the reporter describes only the controversy over, and resolution of, procedural issues; in these cases, the precise nature of the underlying writ cannot by ascertained. See, e.g., Parquot v. Eling, 1 H. Bl. 106, 126 Eng. Rep. 64 (C.P. 1789). Many of the cases in which the writ is unascertainable involve issues of bail of the defendant. See, e.g., 
Table 2

$\begin{array}{llr}\text { Writ } & & \text { No. of Cases } \\ \text { assumpsit } & : & 30(40.5 \%) \\ \text { debt } & : & 17(23.0 \%) \\ \text { ejectment } & : & 7(9.5 \%) \\ \text { trespass } & : & 7(9.5 \%) \\ \text { quare impedit } & : & 4(5.4 \%) \\ \text { replevin } & : & 3(4.1 \%) \\ \text { trespass on the case } & : & 3(4.1 \%) \\ \text { covenant } & : & 2(2.7 \%) \\ \text { de essendo quietum de the- } & & \\ \quad \text { olonio } & : & 1(1.4 \%)\end{array}$

The most common type of assumpsit action was on a bill of exchange. ${ }^{72}$ Disputes of this kind presented the jury with a simple issue based on the documentary evidence of the actual bill, perhaps supplemented by limited testimony.73 The writ of debt was most typically used to secure payment on a bond. ${ }^{74}$ Debt was rarely used to enforce parol contracts, because the trial of such an action was still by compurgation. ${ }^{75}$ Debt on a bond was not tried

Hall v. Walker, 1 H. Bl. 638, 126 Eng. Rep. 364 (C.P 1791).

${ }^{72}$ Six cases were of this type: Harvey v. Richards, 1 H. Bl. 644, 126 Eng. Rep. 368 (C.P. 1791); Brooks v. Rogers, 1 H. Bl. 640, 126 Eng. Rep. 365 (C.P. 1791); Wittersham v. Lady Carlisle, 1 H. Bl. 631, 126 Eng. Rep. 360 (C.P. 1791); Andrews v. Blake, 1 H. Bl. 529, 126 Eng. Rep. 303 (C.P. 1790); Collis v. Emett, 1 H. Bl. 313, 126 Eng. Rep. 185 (C.P. 1790); Kilgour v. Finlyson, 1 H. Bl. 155, 126 Eng. Rep. 92 (C.P. 1789).

${ }^{73}$ See, e.g., Kilgour v. Finlyson, 1 H. Bl. 155, 126 Eng. Rep. 92 (C.P. 1789). In Kilgour, the plaintiff had obtained a verdict against three partners for approximately $\& 304$ on a bill of exchange. The court granted a rule to show cause why a new trial should not be granted, as two of the defendants demonstrated that the partnership had been dissolved and that Finlyson had issued the bill to cover the share of the partnership's debts he had personally assumed.

74 Nine cases were of this type: Haynes v. Hare, 1 H. Bl. 659, 126 Eng. Rep. 376 (C.P. 1791); Sumner v. Brady, 1 H. Bl. 647, 126 Eng. Rep. 369 (C.P. 1791); Newman v. Fancitt, 1 H. Bl. 631,126 Eng. Rep. 360 (C.P. 1791); Scott v. Whalley, 1 H. Bl. 297, 126 Eng. Rep. 174 (C.P. 1789); Duke of St. Albans v. Shore, 1 H. Bl. 270, 126 Eng. Rep. 158 (C.P. 1789); Hays v. Bryant, 1 H. Bl. 253, 126 Eng. Rep. 147 (C.P. 1789); Hobson v. Campbell, 1 H. Bl. 245, 126 Eng. Rep. 142 (C.P. 1789); Orr v. Churchill, 1 H. Bl. 227, 126 Eng. Rep. 131 (C.P. 1789); Folliott v. Ogden, 1 H. Bl. 123, 126 Eng. Rep. 75 (C.P. 1789). A bond was a signed instrument under seal obligating the obligor to pay a sum of money. Simpson, The Penal Bond with Conditional Defeasance, 82 L.Q. REv. 392, 393 (1965).

${ }_{73}$ See J. BAKER, supra note 22, at 268-69. Trial by compurgation, otherwise known as wager of law, was the common mode of trial of many of the older writs, such as debt and detinue:

The party who was called upon to make his law had to find a number of people, twelve or some other number fixed by the court according to circumstances, and then take a solemn oath that he was innocent. His companions, or 'compurgators' as they were called, then swore that the oath which he had taken was clean.

T. Plucknetr, supra note 24, at 115 (footnote omitted). Wager of law was not abolished until 1833. Id. at 116. 
by compurgation; the plaintiff simply won if he produced a facially valid bond, the only issue originally triable to a jury being whether the defendant had in fact issued the written instrument. ${ }^{78}$ In time, the practice arose of allowing a bond to be endorsed with a condition, and the performance of such a condition was triable by jury.77 Nevertheless, the pleadings in an action of debt were limited to a single piece of evidence: what appeared on the bond itself. ${ }^{78}$

Of course, not all of the cases heard in Common Pleas were simple assumpsit or debt actions. The unusual aspects of these more intricate cases, however, generally called for determination by the court of complex or controversial issues of law, which did not involve the jury. ${ }^{79}$ Among the more involved disputes were the quare impedit suits to settle controversies over an advowson, i.e., the right to fill a vacancy in a church position. ${ }^{80}$ These controversies might require the jury to examine documentary evidence stretching back over several centuries. One special verdict traced the title to an advowson back over two hundred years to letters patent granted by Edward VI in $1552 .{ }^{81}$ Nevertheless, since each case could involve only a single advowson, the task of a jury was not substantially more difficult than that of tracing the chain of title to an individual piece of real property.

During the years 1789 to 1791 , only the bankruptcy of Livesay and Company presented a controversy that in number of parties

76 The general issue of "nil debet," or absence of the underlying debt, was not subject to jury trial. See C. Fifoor, History and Sources of the Common Law: Tort and ConTRACT 231-33 (1949).

77 See generally Simpson, supra note 74.

${ }^{78}$ Cf. Haynes v. Hare, 1 H. Bl. 659, 126 Eng. Rep. 376 (C.P. 1791) (parol evidence of redemption option on life annuity refused, as party allegedly agreeing to option was deceased).

79 See, for example, Folliott v. Ogden, 1 H. Bl. 123, 126 Eng. Rep. 75 (C.P. 1789), where the claims of two American loyalists whose property had been confiscated during the American Revolution were at issue. A determination of the status of their business transactions, which began in 1769 , required an analysis of the extent to which certain events during the Revolution had affected those transactions. The Court gave judgment for plaintiff before the matter came to trial, however, because the defendant's averment that a fund existed in New Jersey to pay loyalists' debts that had been attainted by the state did not constitute a plea of payment and was, therefore, an insufficient answer to a writ of debt.

${ }^{80}$ E.g., Barker v. Bishop of London, 1 H. Bl. 412, 126 Eng. Rep. 240 (C.P. 1790); Thrale v. Bishop of London, 1 H. Bl. 376, 126 Eng. Rep. 221 (C.P. 1790). The writ derives its name from its command to the defendant to show quare impedit, literally, "why he hinders," the plaintiff in his possession of the advowson. Quare impedit largely supplanted the assize of darrein presentment and the writ of right of advowson. See 3 W. HOLDSWORTH, supra note 22 , at 24-25.

s1 Arthington v. Bishop of Chester, 1 H. Bl. 418, 419-20, 126 Eng. Rep. 243, 244 (C.P. 1790). The special verdict was probably drafted by the parties and not the jurors. 
and intricacy of financial consequences might at first glance appear to approach the level of complexity of contemporary antitrust or securities cases. During the course of a given year, Livesay and Company often negotiated bills whose total value was as much as one million pounds sterling. ${ }^{82}$ The firm made a practice of drawing the bills payable to fictitious persons and then endorsing them in the names of the fictitious persons over to the firm. ${ }^{83}$ The parties liable on the bills, of course, asserted these fictitious endorsements as a defense. ${ }^{84}$ Although a large number of bills of exchange were involved, each bill had to be sued on in a separate action of assumpsit. ${ }^{85}$ The courts thus resolved the disputes accompanying the demise of the firm without presenting anything other than a simple, one-issue dispute to any single jury. ${ }^{86}$

\section{B. The Court of King's Bench}

For civil disputes, the jurisdiction of the Court of King's Bench differed little from that of Common Pleas. At one time, Common Pleas held a monopoly of jurisdiction over actions to determine title to real property, but by the late eighteenth century King's Bench, through the development of the action of ejectment, had come to be the more common forum for trying possessory rights in real property. ${ }^{87}$ King's Bench, on the other hand, had once had the exclusive power to issue the prerogative writs, ${ }^{88}$ but by the late eighteenth century the other common law courts had completely eroded the exclusivity of the King's Bench's authority

$82 \mathrm{~J}$ ChitTy, Bills of Exchange 58-59 (London 1799).

ss Collis v. Emett, 1 H. Bl. 313, 314-15, 126 Eng. Rep. 185, 186 (C.P. 1790).

s4 Id. at 318-20, 126 Eng. Rep. at 188-89.

8s Id. Further litigation arising from the demise of Livesay and Company appeared in King's Bench. See infra note 127 and accompanying text.

ss Other procedural devices, particularly the special verdict, were also used to prevent the litigation in the Livesay bankruptcy from requiring the jury to pass on complex factual issues. For example, in Collis v. Emett, 1 H. Bl. 313, 126 Eng. Rep. 185 (C.P. 1790), the plaintiff obtained judgment on a special verdict that found that the bill in question should be treated as if it had been made payable to the bearer. Id. at 321, 126 Eng. Rep. at 190. For a discussion of special juries, see Devlin, supra note 3, at 80-83; Oldham, The Origins of the Special Jury, 50 U. CH. L. REv. 137 (1983).

$879 \mathrm{~W}$. HoLDSWORTH, supra note 22, at 4-23.

ss 1 id. at 226, 230-31. The prerogative, or "extraordinary," writs, which included mandamus, non procedendo rege inconsulto, scire facias, ne exeat regno, prohibition, quo warranto, habeas corpus ad subjiciendum, and certiorari, were administrative orders issued through the exercise of the extraordinary power of the king on a showing of proper cause. See de Smith, The Prerogative Writs, 11 Cambridge L.J. 40 (1951); Jenks, The Prerogative Writs in English Law, 32 YALE L.J. 523 (1923). 
and routinely issued these writs. ${ }^{89}$

The Term Reports of Charles Durnford and Edward Hyde East, which cover the civil jurisdiction of King's Bench from 1785 to 1800 , report 362 cases for the period from 1789 to $1791 .{ }^{90}$ These cases include twenty-four criminal informations or indictments, fifteen writs of mandamus, fifty-eight appeals from quarter sessions, thirteen informations in the nature of a quo warranto, six writs of error, and four writs of prohibition; the remaining 242 cases were suits amenable to civil jury trial. Because they required a jury, the thirteen quo warranto cases ${ }^{21}$ have been added to the civil jury cases for statistical purposes. A survey of these 255 cases reveals a pattern strikingly similar to that of Common Pleas.

1. Parties. The tabulation of the number of parties is as follows: ${ }^{92}$

Table 3

No. of Parties

No. of Cases

2

3

4 or more

$170(67.2 \%)$

$44(17.4 \%)$

$39(15.4 \%)$

The typical case in King's Bench, as in Common Pleas, involved a single plaintiff suing a single defendant. In only seven percent of the cases were multiple parties present on both sides. ${ }^{\text {s }}$

See 5 G. JACOB, supra note 30 , at 317; 1 W. ThD, supra note 25, at 36 .

90 These cases appear at 3 T.R. 1 to 4 T.R. 496, 100 Eng. Rep. 423-1139. See C. Durnford \& E. East, Tearm Reports in the Court of King's Bench (London 1817). Durnford and East were the first reporters to publish their reports promptly after the decisions of the cases. Previous reports consisted of lawyer's notes, collected and published many years after the decisions were rendered. $12 \mathrm{~W}$. HoLDSwORTH, supra note 22, at 116. Campbell included Durnford and East among the "very best law reporters that have ever appeared in England." $2 \mathrm{~J}$. CAMpbelt, The Lives of THE ChIBF JusticBs OF ENGLAND 405 (Boston 1850).

91 Although technically a criminal trial, the information in the nature of a quo warranto was used to try a civil right between parties. This action was

properly a criminal method of prosecution, as well to punish the usurper by a fine for the usurpation of [a franchise or liberty against the King], as to oust him, or seize it for the Crown: but hath long been applied to the mere purposes of trying the civil right, seizing the franchise, or ousting the wrongful possessor; the fine being nominal only.

5 G. JACOB, supra note 30 , at 373 (citation omitted).

${ }^{22}$ Two of the cases were conducted ex parte and, therefore, are not considered in the tabulation. See supra notes 58-59 and accompanying text (discussing the methods used in determining the number of parties).

93 The largest number of parties specifically reported in any of the King's Bench cases is twenty-six. In that case, Doe v. Perkins, 3 T.R. 749, 100 Eng. Rep. 838 (K.B. 1790), two lessors sought to eject twenty-four tenants. Because the defendants admitted the plaintiffs' title and only contested the date on which they should have received notice to quit, the case itself was routine and uncomplicated. See id. at 751, 100 Eng. Rep. at 839. 
In most of the cases with four or more parties, the relationships of the parties, as in Common Pleas, ${ }^{94}$ were joint rights or liabilities created by operation of law: thirteen cases involved assignees in bankruptcy, ${ }^{95}$ three involved groups of public officials, ${ }^{96}$ and three involved set of executors. ${ }^{97}$

2. Amounts in Controversy. Twenty-nine percent of the reports of King's Bench cases indicate the amount in controversy. The mean is approximately $£ 1,760$, but the median amount is only $£ 200$. The mean is skewed upwards by one case where the amount in controversy was $£ 60,000 .{ }^{98}$ This figure is almost twice the sum of the amounts mentioned in all the other cases taken together. Omitting this sum, the mean amount in controversy is $£ 915$.

3. The Forms of Action and the Nature of the Claims. Most cases in King's Bench were, like those in Common Pleas, routine common law contract or real property actions. The following chart provides a breakdown of the cases:

9 See supra text accompanying notes 59-62.

ss Smith v. Hodson, 4 T.R. 211, 100 Eng. Rep. 979 (K.B. 1791); Hunter v. Potts, 4 T.R. 182, 100 Eng. Rep. 962 (K.B. 1791); Polleston v. Smith, 4 T.R. 161, 100 Eng. Rep. 950 (K.B. 1791); Kinloch v. Craig, 3 T.R. 783, 100 Eng. Rep 858 (K.B. 1790); Streatfield v. Halliday, 3 T.R. 779, 100 Eng. Rep. 855 (K.B. 1790); Utterson v. Vernon, 3 T.R. 539, 100 Eng. Rep. 721 (K.B. 1790); Hankey v. Smith, 3 T.R. 507, 100 Eng. Rep. 703 (K.B. 1789); Ellis v. Hunt, 3 T.R. 464, 100 Eng. Rep. 679 (K.B. 1789); Hancock v. Entwisle, 3 T.R. 435, 100 Eng. Rep. 663 (K.B. 1789); Hancock v. Haywood, 3 T.R. 433, 100 Eng. Rep. 661 (K.B. 1789); Rollestson v. Hibbert, 3 T.R. 406, 100 Eng. Rep. 646 (K.B. 1789); Collins v. Forbes, 3 T.R. 316, 100 Eng. Rep. 596 (K.B. 1789); Nerot v. Wallace, 3 T.R. 17, 100 Eng. Rep. 432 (K.B. 1789).

os The King v. Shepherd, 4 T.R. 381, 100 Eng. Rep. 1075 (K.B. 1791) (information in nature of quo warranto against churchwardens); Noble v. Durell, 3 T.R. 271, 100 Eng. Rep. 569 (K.B. 1789) (frankpledge jury); Clark v. King, 3 T.R. 147, 100 Eng. Rep. 502 (K.B. 1789) (bailiffs).

${ }^{97}$ Doe v. Woodhouse, 4 T.R. 89, 100 Eng. Rep. 910 (K.B. 1790); Erving v. Peters, 3 T.R. 685, 100 Eng. Rep. 803 (K.B. 1790); Duffield v. Scott, 3 T.R. 374, 100 Eng. Rep. 628 (K.B. 1789).

${ }^{93}$ Petrie v. Benfield, 3 T.R. 476, 100 Eng. Rep. 686 (K.B. 1789). This case, for penalties under the Bribery Act, 2 Geo. 2, c. 24, was allowed to proceed on a copy of the bill made by the plaintiff. The original had been stolen from the file, presumably in an effort to frustrate litigation because of the large amount in controversy. 
Table 4

Writ

assumpsit

No. of Cases

debt $53(20.7 \%)$

ejectment

$34(13.1 \%)$

covenant

$23(9.0 \%)$

trespass

$20(7.8 \%)$

quo warranto

$19(7.4 \%)$

trespass on the case

$13(5.1 \%)$

trover

replevin

detinue

issues from Chancery

$13(5.1 \%)$

$8(3.1 \%)$

$5(2.0 \%)$

$1(0.4 \%)$

$4(1.6 \%)$

miscellaneous

$6(2.3 \%)$

procedural dispute where un-

derlying writ not identifiable

$57(22.3 \%)$

Ordinary contract disputes formed the principal part of the court's business, as the figures for assumpsit, debt, and covenant demonstrate. Approximately one-half of the writs of debt, however, involved statutory causes of action by common informers to recover statutorily imposed penalties. These qui tam actions ${ }^{99}$ were two-party disputes involving rather minor penalties. ${ }^{100}$

The restrictive effects of the writ system on the cases found in the Common Pleas reports is also present in King's Bench. For example, in Hancock v. Haywood, ${ }^{101}$ Hancock and others were the assignees of both Lomas and Edensor. Haywood was in debt to Lomas separately, to Edensor separately, and to Lomas and Edensor jointly. Hancock and the other plaintiffs recovered a verdict in assumpsit on all three debts, but the court arrested judgment on the separate debts, holding that only the joint debt could properly be sued on in a single action. ${ }^{102}$ Similarly, in Ward $v$. Macauley, ${ }^{103}$ the court set aside the verdict and nonsuited the plaintiff on the grounds that only an action in trover would lie to recover goods that were not in plaintiff's possession when taken. And in Smith $v$. Hodson, ${ }^{104}$ the court, finding that the plaintiff-assignees in bank-

20 The name is derived from the phrase "qui tam pro domino rege, quam pro se ipso, sequitur": who as well for our lord the king, as for himself, sues. 3 W. BLAcKstone, supra note 28, at *160; 2 W. JowitT, Dictionary OF ENGLish LAW 1463 (1959).

100 See, e.g., Shipman v. Henbest, 4 T.R. 109, 100 Eng. Rep. 921 (K.B. 1790) (illicit sale of leather); Brooke v. Milliken, 3 T.R. 509, 100 Eng. Rep. 705 (K.B. 1789) (illicit sale of imported reprints of books originally written and published in United Kingdom).

1013 T.R. 433, 100 Eng. Rep. 661 (K.B. 1789).

${ }^{103}$ Id. at 435, 100 Eng. Rep. at 663.

1034 T.R. 489, 100 Eng. Rep. 1135 (K.B. 1791).

1044 T.R. 211, 100 Eng. Rep. 979 (K.B. 1791). 
ruptcy should have brought an action in trover to recover a preference by the bankrupt on the eve of bankruptcy, set aside a verdict for the plaintiffs in assumpsit and entered a nonsuit.

In relative terms, the most complex disputes in King's Bench were those involving ejectment. Forty-three percent of the ejectment cases involved four or more parties; the same number of parties were found in only thirteen percent of the remaining cases. Moreover, resolution of ejectment disputes could call for an examination of evidence of a chain of title that spanned many years, and the rules governing estates in real property were hardly a model of clarity or simplicity. Nonetheless, the law of estates guaranteed that the factfinder would have only a limited number of possibilities to consider, and most of the evidence of title was preserved in writing. In the final analysis, it is difficult to characterize ejectment actions as other than fairly straightforward and routine.

\section{Nisi Prius}

Nisi prius was not a separate court; rather, it was the trial phase of all common law courts. ${ }^{105}$ When sitting at Westminster, the justices would hear pleadings and post-trial motions. Between terms, they would travel to the individual counties where the disputes would be put to juries. ${ }^{106}$ Ordinarily, the justices presided over trials from all of the common law courts, ${ }^{107}$ but the reports available for this period only include cases from the Court of King's Bench.

The nisi prius cases are considered separately from the King's Bench cases at Westminster for two reasons. First, the nisi prius reports provide more direct information about the actual functioning of the jury. Second, the substantial similarity to the results observed in the Westminster cases internally validates these results and thus strengthens the inference that can be drawn as to the limited and routine functions of the jury in common law disputes.

Thomas Peake's nisi prius reports, which are considered high-

${ }^{103}$ The writ [of nisi prius] was so called because it ordered the sheriff to cause jurors, summoned to be present at actions put down for trial in the central courts, to come to Westminster before a named day 'unless before' the circuit justices should visit his county. In fact the justices always came before the day.

R. Pugh, Itinerant Justices in English History 9 n.1 (1967); see 3 W. Blackstone, supra note 28 , at *59.

${ }^{106}$ See $1 \mathrm{~W}$. Holdsworth, supra note 22, at 278-79, 283; T. Plucknetr, supra note 24, at $165-67$.

${ }^{107}$ See 1 W. HoLDSWORTH, supra note 22, at 281. 
ly accurate, ${ }^{108}$ cover the period from 1790 to $1812 .^{109}$ Peake reported eighty-five cases between 1790 and $1791,{ }^{110}$ of which seven were criminal cases. The remaining seventy-eight cases were before a civil jury.

1. Parties. The statistics on parties derived from the nisi prius reports indicate that the nisi prius cases were even simpler than those found in the King's Bench reports:

Table 5

No. of Parties

No. of Cases

2

3

4 or more

$59(75.6 \%)$

$7(9.0 \%)$

$12(15.4 \%)$

Multiple parties were present on both sides of the dispute in only three cases. ${ }^{111}$ The multiple-party cases, as in the Common Pleas and King's Bench cases, usually involved individuals related through participation in a single legal entity, such as a partnership, and thus presented cases differing little from ordinary two-party disputes. Of the twelve actions involving four or more parties, four involved assignees in bankruptcy, ${ }^{112}$ five involved partnerships, ${ }^{113}$ and one involved a group of nightwatchmen. ${ }^{114}$ One of the two remaining cases was sent from Chancery for an advisory verdict on the question "whether the plaintiff was the lawful issue of Charles Standen."116

${ }^{108}$ See 12 W. Holdsworth, supra note 22, at 109-10; 2 J. Wallace, The Reporters Arranged and Characterized with Incidental Remarks 541 n.1 (4th ed. 1882).

100 T. PEAKE, supra note 49.

110 These cases appear at Peake 1, 170 Eng. Rep. 57, to Peake 142, 170 Eng. Rep. 108.

${ }^{111}$ Dawe v. Holdsworth, Peake 89, 170 Eng. Rep. 89 (K.B. 1791); Gorham v. Thompson, Peake 60, 170 Eng. Rep. 78 (K.B. 1791); Licet v. Reid, Peake 49, 170 Eng. Rep. 74 (K.B. 1791).

${ }_{112}$ Dawe v. Holdsworth, Peake 89, 170 Eng. Rep. 89 (K.B. 1791); Henbest v. Brown, Peake 75, 170 Eng. Rep. 84 (K.B. 1791); Licet v. Reid, Peake 49, 170 Eng. Rep. 74 (K.B. 1791); Robert v. Teasdale, Peake 38, 170 Eng. Rep. 71 (K.B. 1790).

${ }_{113}$ Rotheroe v. Elton, Peake 117, 170 Eng. Rep. 99 (K.B. 1791); White v. Boulton, Peake 113, 170 Eng. Rep. 98 (K.B. 1791); Williams v. Dyde, Peake 99, 170 Eng. Rep. 93 (K.B. 1791); Barber v. Blackhouse, Peake 86, 170 Eng. Rep. 85 (K.B. 1791); Gorham v. Thompson, Peake 60, 170 Eng. Rep. 78 (K.B. 1791).

114 White v. Edmunds, Peake 123, 170 Eng. Rep. 101 (K.B. 1791). The action was trespass for assault and false imprisonment. The defendants successfully justified the imprisonment on the ground that they were watchmen conveying one Weeks to the watch-house and that they had apprehended the plaintiff when he attempted to interfere with the arrest of Weeks.

118 Standen v. Standen, Peake 45, 170 Eng. Rep. 73 (K.B. 1791). The case turned upon whether the banns had been published the requisite three times before Charles Standen married the plaintiff's mother. The plaintiff's legitimacy would entitle him to a certain bequest "to the legitimate children of Charles Standen." Id. The case is also interesting for the 
2. Amount in Controversy. Amounts in controversy appear in seventeen percent of the cases. The median amount was $£ 50$ and the mean was $£ 165$. The sums are substantially lower than those found in King's Bench. ${ }^{116}$

3. The Forms of Action and the Nature of the Claims. The seventy-eight cases in the nisi prius reports break down as follows:

Table 6

Writ

No. of Cases

assumpsit

$42(53.8 \%)$

trespass

trover

debt

trespass of the case

ejectment

covenant

$11(14.1 \%)$

$8(10.3 \%)$

$6(7.7 \%)$

$3(3.8 \%)$

$2(2.6 \%)$

writ not identifiable

$5(6.4 \%)$

Although the ejectment figures are lower, ${ }^{117}$ on the whole the basic pattern of litigation shown in the nisi prius reports is much the same as that at King's Bench: ${ }^{118}$ a majority of simple contract actions, mostly assumpsit on a bill of exchange or for goods sold and delivered, followed in frequency by real property and tort disputes.

The typical assumpsit action in the nisi prius reports demonstrates the extent to which the law of evidence restricted the complexity of jury trials. In Kennet $v$. Greenwollers, ${ }^{119}$ for example, the assignees of a bankrupt sued the defendant for money had and received. The court refused to allow the bankrupt to testify because he was interested in the outcome of the litigation. ${ }^{120}$ Other cases show that the court, presuming the jury to be illiterate, might exclude much of the documentary evidence as well. ${ }^{121}$

freedom with which the trial judge commented on the evidence to the jury. Id. at $47-48,170$ Eng. Rep. at 74.

${ }_{116}$ See supra text accompanying note 98.

117 Nine percent of the King's Bench actions were for ejectment, see supra Table 4, while ejectment actions accounted for only $2.6 \%$ of the nisi-prius cases.

128 See supra text preceding note 99.

110 Peake 3, 170 Eng. Rep. 58 (K.B. 1790).

${ }^{120}$ The plaintiffs, therefore, "not having any other evidence were nonsuited." Id. at 4, 170 Eng. Rep. at 58.

121 In Macferson v. Thoytes, Peake 29, 170 Eng. Rep. 67 (K.B. 1790), the plaintiff sought to prove the handwriting of the first endorser on a bill of exchange by showing the jury an admitted sample of the endorser's handwriting for comparison. Lord Kenyon refused to accept the evidence, concluding that the "[c]omparison of hands is no evidence. If it were so, the situation of a Jury who could neither write nor read would be a strange one, 
The questions submitted to juries arose for the most part from straightforward two-party transactions. Typical were issues such as whether the defendant had in fact promised to pay an old debt that had been discharged by bankruptcy, ${ }^{122}$ whether the defendant owed rent quarterly or semi-annually, ${ }^{123}$ whether the defendant could forego payment for medicine because of improper treatment, ${ }^{124}$ whether the defendant had tendered funds sufficient to cover excess expenses incurred under a contract to build a house, ${ }^{125}$ and whether payment of a bill of exchange had been conditioned on the receipt by the defendant of a certain sum from a third party. ${ }^{128}$

Among these cases, Thorton v. Royal Exchange Assurance Co. ${ }^{127}$ involved perhaps the most complex evidentiary situation presented to a jury. The defendant insurer refused to compensate the plaintiff for a shipwreck, on the ground that the ship had not been seaworthy when the insurance policy was issued. The court permitted an expert shipbuilder to testify as to the ship's seaworthiness based on his reading of a written report of an inspection of the ship conducted by other experts at the site of the accident. Because of the contract issues, documentary evidence, and use of expert testimony, this was an unusually complicated case for the period in question. By comparison to modern litigation, however, it seems remarkably routine.

\section{Equity}

As the previous discussion has indicated, "Suits at common law" as conducted at the time of the adoption of the seventh amendment possessed an inherent simplicity. Yet this observation would be of little value in determining the nature of the civil-jury guarantee if suits in equity were as straightforward as those at common law. As the following examination of equity litigation in England during the period of 1789 to 1791 demonstrates, however,

for it is impossible for such a Jury to compare the hand-writing." Id., 170 Eng. Rep. at 68.

${ }^{322}$ Williams v. Dyde, Peake 99, 170 Eng. Rep. 93 (K.B. 1791).

${ }_{128}$ Carter v. Pryke, Peake 130, 170 Eng. Rep. 104 (K.B. 1791).

124 Kannen v. M'Mullen, Peake 83, 170 Eng. Rep. 87 (K.B. 1791).

125 Pepper v. Burland, Peake 139, 170 Eng. Rep. 107 (K.B. 1791).

${ }^{128}$ Phetheon v. Whitmore, Peake 55, 170 Eng. Rep. 77 (K.B. 1791).

${ }^{127}$ Peake 37, 170 Eng. Rep. 70 (K.B. 1790). Disputes arising out of the bankruptcy of Livesay and Company, another relatively complex case, discussed supra notes 82-86 and accompanying text, also appeared in King's Bench. See Minet v. Gibson, 3 T.R. 481, 100 Eng. Rep. 689 (K.B. 1789); Vere v. Lewis, 3 T.R. 182, 100 Eng. Rep. 522 (K.B. 1789); Tatlock v. Harris, 3 T.R. 174, 100 Eng. Rep. 517 (K.B. 1789). 
cases in equity were decidedly more complex.

The Chancery was the principal court of equity in England in 1791. ${ }^{128}$ The Lord Chancellor was the sole judge of the court, and, as the King's chief judicial officer, he exercised jurisdiction to correct the "inequities" of the common law. ${ }^{129}$ Although there were certain established categories of equity jurisdiction, ${ }^{130}$ suits in Chancery were not limited by any procedural system similar to the writ system. Litigation proceeded entirely by document: suit was initiated by a bill, the defendant gave a written answer, and all the evidence was given by deposition. ${ }^{131}$ According to Blackstone:

[A] commission out of chancery . . . for examining witnesses in one cause will frequently last as long, and of course be full as expensive, as the trial of a hundred issues at nisi prius: and yet the fact cannot be determined by such commissioners at all; no, not till the depositions are published and read at the hearing of the cause in court. ${ }^{132}$

1. Parties. Between 1789 and 1791, William Brown reported 226 Chancery decisions. ${ }^{133}$ Unlike the cases brought in the common law courts, multiple-party suits were the norm. In 52 of the 226 reported cases, the number of parties cannot be determined. The remaining cases fall into the following distribution:

Table 7

No. of Parties

No. of Cases

2

3

4 or more

$32(18.4 \%)$

ex parte

$17(9.8 \%)$

The category of four or more parties is by far the largest, a marked contrast to the cases in the common law courts. ${ }^{134}$ Usually

128 See J. BAKER, supra note 22, at 86-89; see also $1 \mathrm{~W}$. HoLDSWORTH, supra note 22, at 395-445 (development of Court of Chancery). Compare 3 W. Blackstone, supra note 28, at $* 49$, with id. at *43. In addition to the equity jurisdiction, there was an older administrative side of the Chancery that issued the writs necessary for the initiation of suits at common law. See 1 W. HoLDSWORTH, supra note 22, at 397-99.

${ }^{129}$ See J. BAKER, supra note 22, at 87-88; 1 W. HoldSwORTH, supra note 22, at 453-59.

130 See J. BAKER, supra note 22, at 93-95; 1 W. HolDSWORTH, supra note 22, at 467-69;

T. PlucknetT, supra note 24 , at 692.

131 Devlin, supra note 12 , at 58-59.

132 W. BLACKSTONE, supra note 28 , at *378-79.

193 W. Brown, Reports of Cases Argued. and Determined in the High Court of Chancery (5th ed. London 1820) (1st ed. London 1785). The relevant cases appear at 2 Bro. C.C. 490 to 3 Bro. C.C. 415 , 29 Eng. Rep. 269-618.

${ }^{134}$ See supra Table 1 (19.0\% in Common Pleas); Table 3 (15.4\% in King's Bench); 
the exact number of parties cannot be determined, because the reports refer to multiple plaintiffs and multiple defendants without identifying the specific parties, although the reporter does occasionally list all parties and explain their relationships to one another in the body of his report. ${ }^{135}$ These relationships tended to be considerably more complex than those in the cases in common law courts. ${ }^{136}$

The ex parte petitions were usually requests for admission as a creditor in bankruptcy proceedings and as such were preliminary to multiple-party litigation. ${ }^{137}$ of the two-party cases, seventeen involved parties to actions at law seeking equitable relief not available in the common law courts, such as discovery ${ }^{138}$ or an injunction to stay trial at law. ${ }^{139}$ Other two-party cases were decidedly more intricate than those in the law courts. For example, Countess Dowager of Shrewsbury v. Earl of Shrewsbury ${ }^{\mathbf{1 4 0}}$ involved a marriage settlement, regulated by a private act of Parliament, in which approximately $£ 20,000$ was in dispute.

2. Amount in Controversy. The amounts in controversy in the Chancery cases were of a different order of magnitude from those in the common law courts. The forty-four percent of the cases that mention the amount in controversy reveal the following distribution:

Table 5 (15.4\% at nisi prius).

195 Where the parties are not listed, enough information is sometimes given about them in the body of the report to indicate the complexity of the suit. See, e.g., Attorney General v. Mayor of London, 3 Bro. C.C. 170, 29 Eng. Rep. 472 (Ch. 1790). In that case, testator had established a trust in 1691 for the advancement of Christianity among the infidels in New England and Virginia. Trustees were the Bishop of London, Earl of Burlington, President of Trinity College, and Mayor of London. They could find no more infidels in those lands and were also uncertain about the effect of the Revolution on an English trust with objects in America. Besides the trustees, defendants included potential beneficiaries, such as the College of William and Mary and the President and Fellows of Harvard College.

${ }^{390}$ E.g., Butler v. Stratton, 3 Bro. C.C. 366, 29 Eng. Rep. 587 (Ch. 1791) (28 descendants of testatrix involved in a dispute over a legacy of London real estate).

${ }^{137}$ E.g., Ex parte Clarke in re Livesay \& Co., 3 Bro. C.C. 238, 29 Eng. Rep. 511 (Ch. 1791). For a discussion of the Livesay and Company litigation, see supra notes 82-86 and accompanying text.

${ }_{13 s}$ See, e.g., Rondeau v. Wyatt, 3 Bro. C.C. 154, 29 Eng. Rep. 462 (Ch. 1790).

199 See, e.g., Codd v. Woden, 3 Bro. C.C. 72, 29 Eng. Rep. 415 (Ch. 1790); Goate v. Fryer, 3 Bro. C.C. 22, 29 Eng. Rep. 386 (Ch. 1789).

${ }^{310} 3$ Bro. C.C. 120, 29 Eng. Rep. 445 (Ch. 1790). 
Table 8

Amounts

No. of Cases

0 to $£ 99$

$3(3.0 \%)$

$£ 100$ to $£ 999$

$34(34.3 \%)$

$£ 1,000$ to $£ 9,999$

$46(46.5 \%)$

$£ 10,000$ and greater

$16(16.2 \%)$

The mean amount was approximately $£ 4116$. The median amount was $£ 1541$. These figures are considerably larger than the comparable amounts in the common law courts. ${ }^{141}$

3. The Nature of the Claims. As a general matter, the equity cases demonstrate a complexity and variability far beyond that evidenced in the common law courts. The most important factor tending to complicate equity cases was the existence of procedural devices unavailable at common law, such as interpleader ${ }^{142}$ and cross bills. ${ }^{143}$ In addition, cases often lasted many years. In Samuda v. Furtado, ${ }^{144}$ for example, the original bill was filed in 1734, more than fifty-five years prior to the reported proceedings; the suit had been abated by the deaths of parties and been revived several times during the intervening years.

\section{ANALysis}

The paradox presented by the seventh amendment is how to give meaning to the command to "preserve" the jury right in "Suits at common law" in the context of modern litigation. Most of the procedural incidents of common law civil trials in 1791 have been abandoned. ${ }^{145}$ The forms of action have been replaced in the Federal Rules of Civil Procedure by a unitary civil action, applicable not only to the suits at law formerly governed by the writ system but also to proceedings in equity. ${ }^{148}$ Joinder of claims has been extended to all claims one party may have against another whatever the nature of the claim, ${ }^{147}$ and joinder of parties has been substantially expanded. ${ }^{148}$ The technical requirement of pleading

142 See supra text following notes 68 (in Common Pleas: $£ 396$ 18s. median, $£ 118018 \mathrm{~s}$. 2/3d. mean), 97 (in King's Bench: $£ 200$ median, $£ 1760$ mean) \& 115 (at nisi prius: $£ 50$ median, \& 165 mean).

142 See, e.g., Dungey v. Angove, 3 Bro. C.C. 36, 29 Eng. Rep. 393 (Ch. 1789).

143 See, e.g., Seton v. Seton, 2 Bro. C.C. 610, 29 Eng. Rep. 336 (Ch. 1789).

143 Bro. C.C. 70, 29 Eng. Rep. 413 (Ch. 1790).

145 See infra notes 146-57 and accompanying text.

146 FED. R. Crv. P. 2 ("There shall be one form of action to be known as a "civil action.' "); see 2 J. Moore \& J. Lucas, Moore's Federal Practice IIT 2.01-2.06 (2d ed. 1984).

147 FED R. Civ. P. 18(a).

148 Fed. R. Civ. P. 19-23, 24-25; see 3A J. Moore \& J. Lucas, Moore's Federal Prac- 
down to a single issue has been abolished, ${ }^{149}$ and, indeed, a party may now plead in the alternative or inconsistently. ${ }^{150}$ The Federal Rules of Civil Procedure also allow many of the procedural devices formerly available only in equity, ${ }^{151}$ such as interpleader, ${ }^{162}$ cross claims, ${ }^{153}$ and class actions, ${ }^{154}$ in jury trials. Under the Federal Rules, the discovery process of the equity courts has essentially been made available in all civil actions. ${ }^{155}$ Furthermore, many of the evidentiary restrictions that existed in 1791 have been eliminated, such as disqualification of interested parties. ${ }^{156}$ These changes in the character of civil litigation are exacerbated by the modern proliferation of novel statutory causes of action. ${ }^{167}$

Of course, not all of the modern developments have expanded the role of the jury. The judicial system has also created procedural devices, such as nonmutual collateral estoppel, ${ }^{158}$ directed verdicts, ${ }^{169}$ summary judgments, ${ }^{160}$ the power to set aside verdicts

TICE IfI 19.01-1[1] (2d ed. 1984) (history of rule 19), 20.03 (prior English permissive joinder practice), 20.04 (prior American permissive joinder practice), 21.03[1] (discussing wholesome repudiation of common law misjoinder practice), 22.03 (former interpleader practice); 3B J. Moore \& J. Kennedy, Moore's Frdrral Practice IT 23.02[1] (2d ed. 1984) (development of class action in equity), 24.03 (development of intervention practice).

${ }^{140}$ See Frd. R. Crv. P. 8(e)(1).

${ }^{180}$ Id. 8(e)(2).

161 For discussion of the limitation of cross claims and class actions to equity, see $3 \mathrm{~J}$. Moore \& J. Lucas, Moore's Federal Practice II 13.34[2] (2d ed. 1984) (cross claim practice prior to federal rules); 3B J. Moore \& J. Kennedy, Moore's Federal Practice 1 23.01 [2] \& nn.1-19 (2d ed. 1984) (development of the class action in English Chancery). A common law writ of interpleader had existed, but interpleader was in fact always brought in equity. Compare Z. Chapee, Cases on Equitable Remedies 1 (2d ed. 1939) (equitable interpleader supersedes legal interpleader because juries are unable to handle interpleader issues), with Rogers, Historical Origins of Interpleader, 51 YALE L.J. 924, 932-47 (1942) (rise of equitable interpleader caused by restriction of legal interpleader to defensive use).

${ }_{182}$ Frd. R. Crv. P. 22; see also 28 U.S.C. $\$ 1335,1397,2361$ (1982) (interpleader statutes). See generally F. JAMES \& G. HAZARD, supra note 6, § 10.21 (overview of interpleader); 3A J. Moore \& J. Lucas, Moore's Federal Practice T 22.02[2] (2d ed. 1984) (scope of interpleader).

${ }^{153}$ Fed. R. Civ. P. 13; see F. JAMES \& G. HAZARD, supra note 6, § 10.14. Counterclaims were not available in equity, but were a creation of the Field Code. Set-off, however, served much the same purpose. See id. $\$ 10.16$.

156 FED. R. Crv. P. 23; see F. JAMES \& G. HAZARD, supra note 6, § 10.18.

158 See Frd. R. Civ. P. 26-37. Compare 4 J. Moore \& J. Lucas, Moore's Federal PracTiCE If 26.03[1] (2d ed. 1984) (former practice at law), with id. I 26.03[2] (former practice in equity). A separate action in Chancery could sometimes be used to compel discovery for an action at common law. See Devlin, supra note 3, at 54 (auxiliary equity); supra note 138 and accompanying text.

${ }^{158}$ See FED. R. Evid. 601. See generally Bodansky, supra note 41 (discussion of abandonment of disqualification of interested parties).

${ }^{167}$ See supra note 8.

158 See Parklane Hosiery Co. v. Shore, 439 U.S. 322, 333-37 (1979).

${ }^{230}$ See Galloway v. United States, 319 U.S. 372, 388-96 (1943). 
in part, ${ }^{161}$ and remittitur, ${ }^{162}$ in order to provide the court with a means of checking jury abuse. These devices, however, serve principally to check the discretion of the jury, not to reduce the number or complexity of the issues it must decide. ${ }^{163}$

The survey presented in Part III of litigation in the common law courts of England just prior to the ratification of the seventh amendment highlights the degree to which the phrase "trial by jury" would have called to the minds of the framers of the seventh amendment the simplest and most straightforward of procedures. The search for a complex-case exception to the seventh amendment $^{164}$ that has engaged some authors is, therefore, misguided, because "complex" cases did not and could not occur in the common law system to which the framers were accustomed. The remainder of this Part explores the existing law on the scope of the seventh amendment right to trial by jury and suggests that the current law be modified to account for the effects of the pervasive procedural changes in civil litigation since 1791.

\section{A. Current Judicial Interpretation of the Seventh Amendment}

The problem of determining what was meant by the command to "preserve" the right to a jury trial in civil actions existed even at the time the seventh amendment was adopted, because the new republic had no uniform or long-standing tradition of its own from which to draw. ${ }^{165}$ To fill this void the Supreme Court has, from its earliest pronouncements, interpreted the seventh amendment as calling for preservation of the jury right as it existed in the superior common law courts of England in $1791 .^{186}$ The consequence of this interpretation was the retention, for the limited purposes of

180 See Fidelity \& Deposit Co. v. United States, 187 U.S. 315 (1902).

161 See Gasoline Prods. Co. v. Champlin Ref. Co., 283 U.S. 494 (1931).

${ }_{162}$ See Dimick v. Schiedt, 283 U.S. 474, 484-85 (1935).

${ }^{163}$ See F. JAMES \& G. HAZARD, supra note 6, $\$$ 7.12-7.22 (controlling the jury).

${ }_{164}$ See supra notes $13-14$ and accompanying text.

${ }_{163}$ See Henderson, supra note 16, at 299-320; Wolfram, supra note 16, at 712-18.

${ }_{168}$ In United States v. Wonson, 28 F. Cas. 745 (C.C.D. Mass. 1812) (No. 16,750), Justice Story, sitting on circuit, stated that "[b]eyond all question, the common law . . . alluded to [in the seventh amendment] is not the common law of any individual state, (for it probably differs in all), but it is the common law of England, the grand reservoir of all our jurisprudence." Id. at 750. Story declined, however, to explain fully his reasoning for this conclusion: "It cannot be necessary for me to expound the grounds of this opinion, because they must be obvious to every person aquainted with the history of the law." Id. In a later Supreme Court opinion, Story explained that "the phrase 'common law,' . . is used in contradistinction to equity and admiralty, and maritime jurisprudence." Parsons v. Bedford, 28 U.S. 433, 446 (1830). The 1791 date was settled on in later cases. See, e.g., Baltimore \& Carolina Line, Inc. v. Redman, 295 U.S. 654, 657 (1935); Dimick v. Schiedt, 293 U.S. 474, 476 (1935). 
determining the scope of the jury right, of the dichotomy between law and equity. If a plaintiff's claim would have been cognizable in a 1791 English common law court, where juries were usually the triers of fact, then he would be entitled to a jury trial. ${ }^{167}$ If, however, his claim could only have been brought in a court of equity, where the chancellor alone was the trier of fact, ${ }^{168}$ then a jury trial is not available in the federal courts. ${ }^{169}$

The application of this rule to simple real-property, tort, or contract claims, for which forms of action existed in 1791, is relatively straightforward. But the law did not stand still in 1791, and new procedures and causes of action made a literal application of a historical test for preserving the right to trial by jury inadequate. ${ }^{170}$ Justice Story, writing for the Court in Parsons v. Bedford, ${ }^{171}$ concluded that as used in the seventh ammendment the phrase "Suits at common law" meant,

not merely suits, which the common law recognized among its old and settled proceedings, but suits in which legal rights were to be ascertained and determined, in contradistinction to those where equitable rights alone were recognized, and equitable remedies were administered .... In a just sense, the amendment then may well be construed to embrace all suits, which are not of equity or admiralty jurisdiction, whatever may be the peculiar form which they may assume to settle legal rights. ${ }^{172}$

This passage has been interpreted as adopting a "flexible" historical approach to implementing the civil-jury guarantee. ${ }^{173}$ This

${ }^{167}$ For example, suits for damages under the antitrust laws are normally subject to jury trial, because statutory causes of action for treble damages existed and were so tried in 1791. See Beacon Theatres, Inc. v. Westover, 359 U.S. 500, 504 (1959); see also supra note 5 (actions of debt for statutory penalties).

18s See Devlin, supra note 12 , at 50, 58-59.

${ }^{169}$ For example, proceedings in bankruptcy are not subject to jury trial even when they involve disputed claims, because such proceedings have always been conducted in equity. Katchen v. Landy, 392 U.S. 323, 336-37 (1966).

120 In fact, strict adherence to the procedural forms of England in 1791 would not have been possible even at the time the amendment was adopted. Each of the English common law courts, having developed from a different source at a different time, had procedures somewhat different from each of the others. Thus, there was no one "common law procedure" even in 1791, but rather a procedure of Common Pleas, a procedure of King's Bench, and procedure of Exchequer. Even in 1791, an American court would have been unable to find a single procedural system to which to refer.

12128 U.S. 433 (1830).

122 Id. at 446.

173 See 5 J. Moore, J. Lucas \& J. Wicker, Moore's Federal Practice If 38.11 (2d ed. 1982). 
approach permits the judiciary to adapt to the waning of the common law forms of action and their accompanying procedures. ${ }^{174}$ Under this approach, a court's primary focus in determining whether there exists a right to jury trial in a given case is on the nature of the rights and remedies at issue in the case, rather than on the overall character of the entire proceeding. ${ }^{175}$ A court must look beyond the procedural posture of the case and consider whether the right at issue or the remedy requested is analogous to a right or remedy found at common law in $1791 .{ }^{176}$ If there is a sufficient resemblance, a jury trial is required. ${ }^{177}$ By adopting this approach, the Supreme Court has allowed the development of procedural devices that did not exist in 1791 without circumventing the right to civil jury trial. ${ }^{178}$ In short, one can say that the seventh amendment is currently interpreted as intended to preserve "the basic institution of jury trial in only its most fundamental elements, not the great mass of procedural forms and details, varying even [in 1791] so widely among common-law jurisdictions." "178

This framework seems wholly consonant with the spirit of the seventh amendment. It is reasonable to assume that the framers foresaw an evolution of the common law and did not intend for the jury right to be lost as soon as any major judicial reform was implemented. Neither the language of the amendment, nor the available legislative history, ${ }^{180}$ however, supports the conclusion that

174 See, e.g., Ross v. Bernhard, 396 U.S. 531, 539 (1970) (legal claims in derivative suit triable by jury even though "older procedures, now discarded" had prevented such suits); Beacon Theatres, Inc. v. Westover, 359 U.S. 500, 507 (1959) (adequacy of legal remedy must be judged in light of remedies now available, not "discarded procedures").

${ }_{17 s}$ See Ross v. Bernhard, 396 U.S. 531, 538 (1970) (legal issues in derivative suit triable to jury); Simler v. Conner, 372 U.S. 221, 223 (1963) (declaratory action for attorney's fees triable to jury); Dairy Queen, Inc. v. Wood, 369 U.S. 469, 477 (1962) (claim for money judgment triable to jury despite characterization as equitable accounting); Beacon Theatres, Inc. v. Westover, 359 U.S. 500, 504 (1959) (treble damage issues juriable despite presentation in declaratory action).

${ }^{178}$ See Beacon Theatres, Inc. v. Westover, 359 U.S. 500 (1959).

177 See, e.g., Pernell v. Southall Realty, 416 U.S. 363, 375 (1974) (District of Columbia statutory right to recover possesson of real property resembles common law ejectment); Ross v. Bernhard, 396 U.S. 531, 539 (1970) (corporate claims identical whether sued upon directly or derivatively).

${ }_{178}$ See Parklane Hosiery Co. v. Shore, 439 U.S. 322 (1979) (nonmutual collateral estoppel); Galloway v. United States, 319 U.S. 372 (1943) (directed verdict); Gasoline Prods. Co. v. Champlin Ref. Co., 283 U.S. 494 (1981) (setting aside of verdict in part); Fidelity \& Deposit Co. v. United States, 187 U.S. 315 (1902) (summary judgment).

120 Parklane Hosiery Co. v. Shore, 439 U.S. 322, 337 (1979) (quoting Galloway v. United States, 319 U.S. 372,392 (1943)).

${ }^{180}$ See Henderson, supra note 16, at 291-99 (legislative history appears to be silent on this subject); Wolfram, supra note 16, passim (state ratifying conventions concerned with need for, not limits on, civil jury trial). 
the framers intended that the focus of an inquiry into the limits of the right to a civil jury be only on the "substantive" aspects of the trial, that is, the rights asserted and the remedies sought, and never on its procedural elements. Accepting that the seventh amendment's explicit call for the "preservation" of rights existing at the time of ratification implies that a historical perspective is constitutionally required, ${ }^{181}$ there still remains a question as to whether, if one departs too far from the procedural aspects of jury trials as they were conducted in 1791 , one can still be said to be preserving the right to jury trial.

As the survey and preceding discussion indicate, "complex" cases, as we understand that term today, simply did not occur in the common law system known to the framers. Insofar as analogies based on complexity are appropriate, complex modern litigation bears much closer resemblance to equitable actions in 1791 , heard without a jury, than to common law actions. Nonetheless, it would probably also be incorrect to conclude from this fact alone that modern complex litigation, such as one finds in actions brought under the securities or antitrust laws, falls outside the protection afforded the civil jury right by the seventh amendment.

The defect in the existing analysis of the seventh amendment is that it pays too little attention to the enormous differences between civil litigation in 1791 and civil litigation today. The framers, schooled in the traditions of the British legal system, ${ }^{182}$ were undoubtedly aware of the restricted scope of actions at common law, as well as the limited role of the jury. It seems likely that they were also aware of the reasons for the narrow ambit of the common law jury system. By "preserving" the distinctions between law and equity, they tacitly acknowledged that the right to a jury trial should not extend to those situations where the jury would be an inappropriate fact-finding body. ${ }^{183}$ Their conception of a "Suit[] at

181 See Dimick v. Schiedt, 293 U.S. 474, 476 (1935) ("[T]he word 'jury' and the words 'trial by jury' were placed in the Constitution of the United States with reference to the meaning affixed to them in the law as it was in this country and in England at the time of the adoption of that instrument . . .."), (citing Thompson v. Utah, 170 U.S. 343, 350 (1898)).

112 See Henderson, supra note 16, at 299 (civil jury practice differed in each of the thirteen colonies because each borrowed from a slightly different period of English practice); see also L. Frizdman, A Hrstory of Ambrican Law 29 (1973) (American law became more English after Revolution than before); id. at 126-28 (use of English civil procedure); G. GLLMORR, The AgBS Of AMBrican LAw 19 (1977) (use of English legal sources and education).

16s It is possible that the framers intended for the role of the jury in the legal system to remain narrow. The amendment does not mandate that all factfinding be performed by a jury. The language explicitly preserves the jury right only for "Suits at common law," 
common law" must have embodied these notions as much as it embodied notions about the types of rights cognizable and remedies available in the common law courts. Under modern rules of pleading and procedure, a case may be brought that bears so little resemblance to anything that could ever have occurred in the common law courts in 1791 that the difference between them is more aptly called a difference in kind, rather than in degree. Submission of such a case to a jury represents a repudiation, rather than an application, of a historical test. One might as easily assert that a jury is appropriate because the litigation is conducted in a courtroom that was in use in 1791.

In most cases, the current doctrine's focus on the "substantive" aspects of the case, the remedies and rights, may be appropriate. It is, however, futile to assume that an unwavering line can be drawn between substance and procedure. ${ }^{184}$ More importantly, it flies in the face of a claimed reliance on history ${ }^{185}$ to conclude that, in an action involving, for example, over 100 parties contesting eighteen consolidated class actions, with cross claims so numerous as to require a five-page chart merely to list them and a trial expected to last two years and involve about 500 witnesses and 24,000 documents, a jury is constitutionally required simply because the plaintiffs seek money damages, a remedy traditionally granted at law. ${ }^{186}$ When one considers that the modern rules on class actions, discovery, and joinder of parties and claims are all derived primarily from equity, ${ }^{187}$ it is an abandonment, rather than an application, of a historical view of the seventh amendment to call such an action a "Suit[] at common law." Stated differently, even if one accepts the Court's current focus on substantive rights and remedies, there comes a point at which the changes in procedure have been so extensive that there has been a change in the

thereby excluding juries from admiralty, maritime, and, most importantly, equity cases. See United States v. Wonson, 28 F. Cas. 745, 750 (C.C.D. Mass. 1812) (No. 16,750) (Story, J.).

${ }^{184}$ Drawing such a line is especially difficult under a test that refers to the old common law, dominated by the forms of action. As Maine so memorably said, "So great is the ascendancy of the Law of Actions in the infancy of the Courts of Justice, that substantive law has at first the look of being gradually secreted in the interstices of procedure . . ." H. MaINE, Dissertations on Early LaW and Custom 389 (1883); see F. MaITland, supra note 29, at 12.

${ }^{185}$ See supra notes 166, 181.

${ }^{188}$ In re U.S. Fin. Sec. Litig., 75 F.R.D. 702 (S.D. Cal. 1977), rev'd, 609 F. 2 d 411 (9th Cir. 1979), cert. denied, 446 U.S. 929 (1980). The figures for witnesses and documents are. based on the trial judge's estimate that the defendants would present at least as much evidence as the plaintiffs, who had announced their intention to call 241 witnesses and offer nearly 12,000 documents, 75 F.R.D. at 707. See supra note 9.

${ }_{187}$ See supra notes $146-56$ and accompanying text. 
substantive character of the action as well. When such a point is reached, an effort to distinguish cases on the basis of the rights asserted and the remedies sought seeks to preserve the right to a jury trial in what can no longer in any realistic sense be called a suit at common law.

The ultimate question is determining when that point has been reached. As with other constitutional standards, ${ }^{188}$ a determination as to the availability of a jury trial should depend on a consideration of the totality of circumstances in light of a number of relevant factors. These include not only the nature of the rights and remedies, but also the number of parties, the relations they bear to one another, the complexity of the legal and factual issues, the number of claims, and the amount and complexity of the evidence that will be adduced to establish those claims. If the case is so complex because of the combination of flexible procedure and intricate substantive inquiries that, except for the remedy sought, it bears no resemblance whatsoever to suits heard in the English common law system, it is simply not an action for which the jury right can be said to be "preserved."

\section{CONCLUSION}

The seventh amendment calls for the preservation of the right to a jury trial in "Suits at common law." In implementing this constitutional provision, the Supreme Court has developed a "flexible" historical test that focuses primarily on the substantive aspects of the litigation, namely the rights asserted and remedies sought. This comment has argued for a reevaluation of the jury right under the seventh amendment. Statistical analysis of litigation in the common law and equity courts of England during the period of 1789 to 1791 demonstrates that, by comparison to the equity courts, common law cases were very narrow in scope and, by virtue of the existing procedural system, complex cases were not possible at common law.

The implications for the seventh amendment are clear. The jury the framers sought to preserve was an institution severely constrained by procedural limitations. The seventh amendment, of course, does not command strict adherence to common law procedure. Subsequent development of procedure was inevitable, and it

${ }^{188}$ See, e.g., Mathews v. Eldridge, 424 U.S. 319 (1976) (factors to be considered in determination of due process); United Mine Workers v. Gibbs, 383 U.S. 715 (1966) (pendent jurisdiction); Schneckloth v. Bustamonte, 412 U.S. 218 (1973) (consent search under fourth amendment). 
is unlikely that the framers intended for the jury right to be extinguished by every deviation in procedure. Nonetheless, procedural context is not irrelevant. The effect of liberalizing the modern rules of procedure so as to allow increasingly complex litigation has altered the substantive character of civil disputes.

In applying the historical test mandated by the seventh amendment, the courts should consider the overall character of the litigation. If, in fact, the suit, because of the combination of procedural and substantive complexity, is undoubtedly well beyond the framers' understanding of "Suits at common law," no party should have a right to demand a jury trial.

Douglas King 